Kapus, Erika. "Menyhért, Anna. 2016: Egy szabad nö, Erdős Renée regényes élete ('A Free Woman, The Remarkable Life of Renée Erdős'). Budapest: General Press. 231 pp. Illus.” Hungarian Cultural Studies. e-Journal of the American Hungarian Educators Association, Volume 10 (2017) DOI: 10.5195/ahea.2017.304

\title{
Menyhért, Anna. 2016: Egy szabad nö, Erdös Renée regényes élete ('A Free Woman, The Remarkable Life of Renée Erdős'). Budapest: General Press. 231 pp. Illus.
}

\author{
Reviewed by Erika Kapus ", Eötvös Loránd University
}

Anna Menyhért's Egy szabad nö ['A Free Woman'] appeared in Hungary in June 2016, a time when Menyhért (b. 1969) was already a well-known name for Hungarian readers as a children's-book and fiction writer, as well as a poet and columnist writing for literary journals. In addition to all these, Menyhért is also a professor of literary studies at the University of Amsterdam School for Heritage, Memory and Material Culture, acting at the Slavonic Studies Department as a Marie Sklodowska-Curie Individual Research Fellow, where she focuses on trauma writing and women's literary tradition. Her third academic book, Nöi irodalmi hagyomány ['Women's Literary Tradition'] (2013) was heralded by critics as a pioneering work that analyzes the reasons for the exclusion of Hungarian women writers from the country's literary canon and the ways in which they could re-centralize their writing by building their own counter-canon.

One of the examined five authors of Menyhért's groundbreaking study is Renée Erdős (1879-1956; b. as Regina Ehrental to an Érseklél rural Orthodox Jewish family), on whose life the biographical novel or "biofiction" Egy szabad no" is focused. The first chapter of this work has been translated and can be read in English on Menyhért's webpage (at:

http://www.menyhertanna.hu/a-free-woman-first-chapter-in-english). Menyhért also wrote a script on Erdős for Hungarian Television, which became the first episode of a documentary series titled Asszonysorsok és nöszerepek az irodalomban ['Women's Lives and Women's Roles in Literature'] (directed by Kata Oláh, 2014). Menyhért's preoccupation with the figure of Erdös reflects her wish or commitment to understand the reasons why Erdös could become such a popular writer in her own time, yet almost unknown nowadays. Menyhért also emphasizes the importance of the mutual dependence of the author's private and professional life when dealing with a woman writer and her career.

The main driving force of Erdős, as Menyhért draws her figure in her novel, is to become an independent writer with a decent salary. Erdős was indeed the first woman writer in Hungary who was able to make a living from writing, and she even bought a villa from her honorarium. Though the earliest momentum of Erdös's story as depicted in the novel is when she loses her virginity in a hotel room, with a stranger, the novel actually starts with a later sensation, the

\footnotetext{
*kapuse@gmail.com
}

$($ (c) $)$ EY

ULIS D-Serk
New articles in this journal are licensed under a Creative Commons Attribution 4.0 International License.

This journal is published by the University Library System of the University of Pittsburgh as part of its D-Scribe Digital Publishing Program and is cosponsored by the University of Pittsburgh Press 
shocking news about the suicide attempt of her ex-lover, the then famous writer and journal editor, Sándor Bródy (1863-1924). Erdös's loss of virginity signals the starting point of her life as an adult woman, and it is followed by the beginning of her professional writing career at a newspaper called Egyetértés ['Agreement']. From then on, these two threads weave into each other right up to the breaking point in her life, when her ex-lover Bródy attempts to commit suicide. Though Bródy survives, public opinion turns against the "tempting woman", and the literary and journalist communities blame Erdős for Bródy's condition and refuse to publish her texts of poetry and feuilletons (she even had some notes and plans toward starting a new journal for women at that time but was unable to carry out those plans). This is the point when Erdős has to leave Hungary to recover her life and career.

The novel's time management largely follows the chronology of the events but it does so with a twist: the novel begins with Bródy's attempted suicide and ends with its outcome, the breakup between Bródy and Erdős. These purposeful selection and arrangement of central events in Erdös's life are meant to recreate her image as a free woman by shaping her figure as an independent, self-made twentieth-century new woman, all of which are phrased in Erdös's own words at the novel's conclusion: "I was yours, from now I will be mine" ['A magáé voltam, most a magamé leszek'] (201). The genre of biofiction allows Menyhért to play with the relations between reality and fiction in her work. Biographical fiction is of course not a new literary genre, dating back to ego-writings of venerable personages, and the tension between real, historical events and made-up fictional ones has always stood at the core of this mode of writing. Nevertheless, as current, postmodernist writing trends show, the number and popularity of these biographic works have been increasing in the last decades. Biofiction, as Alain Buisine who coined this term describes in his 1991 article, is by its nature a transgressive genre (Alain Buisine, "Biofictions," Revue des Sciences Humaines 224, 1991, 7-13), wherein "the biographer has no choice but to become a historian, and the chronicler to become a novelist" ['Le biographe, ici, n'a d'autre choix que de se faire historien, et le chroniqueur n'a d'autre ressource que de devenir romancier'] (Buisine's citing of Pierre Mertens's work in "Biofictions," 11).

Indeed, combining elements of academic and fictional writing within the frame of transgressive or cross-genre writing is also central in Menyhért's new book. Despite her citing of dates and locations as titles of parts in her book, rather than a diary, Menyhért's narrative reminds us of a biographical novel with many time gaps, for which the genre of fictional biography offers possibilities of filling in. In the Epilogue, Menyhért says that Erdős's life-story is very fragmented, and that she therefore had to research it as well as other materials thoroughly to be able to reconstruct it. Erdős's novels and poems further exemplify the need for Menyhért's reconstruction project: Erdős's yet unpublished 1950s autobiography, Ifjúságunk ['Our Youth'], as well as her earlier, 1920s autobiography-like novel, Az élet királynője ['The Queen of Life'], together supply the bone for the sujet, the concise or chosen plot, of Menyhért's Egy szabad nö. For example, there are shorter and longer citations from Erdős's two novels in Menyhért's novel. Even the strongest scene in the novel, when the paperboy shouts out the headline about Bródy's attempted suicide, should sound familiar to those who have read Az élet királynöje, yet this does not diminish the force of Menyhért's work, but rather makes its reader a participant in an interesting postmodern experiment. The same is true of other insertions of original materials of Erdős in the novel about her life. Chapters always begin with her poems, and parts of her letters 
Kapus, Erika. “Menyhért, Anna. 2016: Egy szabad nő, Erdős Renée regényes élete ('A Free Woman, The Remarkable Life of Renée Erdős'). Budapest: General Press. 231 pp. Illus.” Hungarian Cultural Studies. e-Journal of the American Hungarian Educators Association, Volume 10 (2017) DOI: 10.5195/ahea.2017.304

integrated into the novel serve as strong representatives, or representations, of the authentic voices of herself as of her friends and surroundings.

If we try to place Erdös's character among the heroes and heroines of similar contemporary biofictions, it becomes apparent that her life-story is not as well documented as, for example, that of Virginia Woolf. This does not mean that Menyhért's hands were less tied by reality than were, for example, those of Priya Parmar, the author of the novel Vanessa and Her Sister (2015) about Vanessa Bell and Virginia Woolf. The reading public already knows a lot about the members of the Bloomsbury group, but almost next to nothing about writers and editors surrounding Erdős in Hungary. And, of course, Menyhért does not have less freedom than English novelist A.S. Byatt, who likewise wrote about the lives of real people, just because her characters are not fictional. Parmar notes in her Epilogue that "It is not easy to fictionalise the Bloomsbury Group, as their lives are so well documented. [...] The characters in the novel are very much fictional creations" (346). In other words, fiction and reality should not be imagined like the two opposite endpoints of an axis, but more like being constructed continuously within one and the same text. Even the writer of a diary or an autobiography can only represent his/her own memories as a subjective or fictional construction, and not as facts, not to speak of a researcher who finds life-documents and uses them with caution, or of a researcher whose characters were real but have not left behind too much written memories. Thus, the main question about Menyhért's novel is not how strictly she used manuscripts and other documents, but how valid, authentic, and credible the microworld she has created seems, and this depends on the opinion of each of her readers.

The mutual voice of both heroines in Erdős's novels, as well as of Erdös as the heroine of Egy szabad nö, is that of the woman's body, as theorized decades after the time of Erdös's writings by the term "writing the body" in l'écriture feminine (see: Ann Rosalind Jones, "Writing the Body," at: webs.wofford.edu/hitchmoughsa/Writing.html). This voice was a pioneering phenomenon in the turn-of-the century Hungarian literature, wherein Erdös was considered the main writer who had enough courage to write about sexuality as a woman and about the secrets of a woman's body in her novels. Thus, the first chapter of the second part in Egy szabad nö tells us how the heroine lost her virginity in a hotel room, with a stranger. Readers also meet a rich lesbian girlfriend of Erdös, which is an almost obligatory figure or trope in connection with female artists, and here Erdős, like other writers of the turn-of-the-century and notwithstanding her own pleas for sexual freedom, presents lesbianism as an illness or disability: "Poor Erzsi, God made a mistake in her, and she loves me, she loves a woman" ['Szegény Erzsi, valamit az Isten elvétett benne, és engem szeret, egy asszonyt szeret'] (44).

Menstruation, women's orgasms, contraception, and even the rejection of motherhood all make their appearance in Erdös's work, although only in her later novels of the 1920s and 1930s. Menyhért's novel, however, assigns to Erdős the freedom to write about these taboo issues prematurely as it were, meaning to her work as a young, beginning poet and journalist, much before she became a popular novelist. This time shift enables Menyhéđrt to emphasize the importance of sexuality in Erdös's writing, which is essential in tying together the private and public spheres in her life and novels. The tying together of these two spheres also makes it possible for the heroine of Menyhért's novel to appear as a free and independent woman both as a young woman with sexual desires who knows what she wants and as a talented writer who can earn the money she needs to manage her own life. 
Although Menyhért's novel ends with an earlier event in Erdős's real life (her break-up with Bródy) than the one it began with (Bródy's attempted suicide), the reader feels almost sorry, on the last pages, to part with this wiser and more mature woman. Due to the incident with Bródy and its consequences, the readers first meet a confused, frightened and painful young woman, who eventually rises to be a strong and determined woman ready to manage her own life by herself. Despite the fact that in Erdös's real life the latter actually existed earlier than the former, the readers "grow" with her and finally leave her and the story of her life with positive and optimistic feelings. In other words, Menyhért not only shows to her readers what a free woman looks like, but she also makes them believe in her heroine's power to free herself, as expressed in the novel's ending, by lines taken from Erdős's poem "Me, the Poet" ['Én, a költő']:

Me, the human, belong to myself.

My soul is free, clear and clean.

I never wonder which is bigger:

My womanhood or my love for poetry?

Neither of them will ever get over me!

I will beat them - as you have seen.

And with a cold smile, proudly, like a man

I will face the whole world.

[Én, az ember, a magamé vagyok.

Szabad, világos és tiszta a lelkem.

Sohsem tünödöm rajta, mi nagyobb:

Asszonyiságom, vagy költö-szerelmem?

Ez vagy amaz fölém sohsem kerül!

Lebirom öket - te magad is láttad.

S hideg mosollyal, büszkén, emberül

Nézek szemébe az egész világnak.] (203). 